\title{
RESPON SISWA PADA PENGEMBANGAN MEDIA PEMBELAJARAN: IMPLEMENTASI PADA MATA PELAJARAN TIK KELAS VIII DI SMP NEGERI 4 DENPASAR
}

\author{
Evy Maya Stefany \\ Teknologi Pembelajaran, Pascasarjana, Universitas Pendidikan Ganesha \\ Singaraja, 81116, Indonesia \\ mava_stefany@ymail.com
}

\begin{abstract}
Abstrak
Penelitian ini bertujuan untuk mengetahui respons siswa pada mata pelajaran TIK di kelas VIII SMP Negeri 4 Denpasar terhadap pengembangan media pembelajaran. Jenis penelitian yang digunakan dalam penelitian ini adalah Penelitian dan Pengembangan dengan model pengembangan Dick and Carey. Penelitian ini melibatkan siswa kelas VIII SMP Negeri 4 Denpasar. Data tentang sumber belajar siswa diperoleh dengan menggunakan metode wawancara. Selanjutnya produk diujicobakan kepada siswa melalui tiga tahap, yaitu uji coba perorangan, uji coba kelompok kecil, dan uji coba lapangan. Subyek uji coba penelitian ini terdiri dari 3 siswa untuk uji coba perorangan, 12 siswa untuk uji coba kelompok kecil, dan 35 siswa untuk uji coba lapangan. Data yang dikumpulkan dalam penelitian ini adalah data dari uji ahli materi, uji ahli desain, uji ahli media pembelajaran, dan dari uji coba siswa. Validasi media pembelajaran serta respons siswa dan guru diperoleh dengan menggunakan metode angket. Data yang diperoleh tersebut dianalisis secara deskriptif. Hasil penelitian dari uji coba lapangan dengan tingkat pencapaian $93,14 \%$ berada dalam kategori sangat baik. Pengembangan media pembelajaran ini berada pada kategori sangat baik sehingga media pembelajaran ini layak digunakan dalam pembelajaran.
\end{abstract}

Kata Kunci: media pembelajaran, respon siswa, TIK 


\begin{abstract}
This is a research aims to knowing responses of students and teachers of ICT subjects in class VIII Junior High School 4 Denpasar towards the development of learning media. Types of research used in this study is research and development with Dick and Carey model of development The study involved students in grade VIII Junior SMP 4 Denpasar. Data on student learning resource was is obtained by using interviews. The next product tested to the students through three stages, namely the individual trials, small group testing, and field trials. The subjects of this research trial consisted of 3 students for individual trials, 12 students for small group trials, and 35 students for field trials. Data collected in this study are data from the test material experts, expert test design, test media expert learning, and students from the trial. Validity of the learning media as well as student and teacher responses obtained using the questionnaire method. The data obtained were analyzed descriptively. The results of field trials with the achievement of $93.14 \%$ is in very good category. Development of instructional media is in a category very well that this is worth learning media used in the study.
\end{abstract}

Keywords:learning media, student response, TIK 


\section{Pendahuluan}

Perkembangan Teknologi Informasi dan Komunikasi di berbagai sektor berpengaruh secara signifikan terhadap pribadi maupun komunitas, mulai dari aktivitas kehidupan, metode belajar, gaya hidup sampai cara berfikir di berbagai bidang termasuk bidang pendidikan. Dengan demikian, pemanfaatan TIK mutlak diperkenalkan kepada siswa dengan tujuan agar mereka memiliki pengetahuan dan pengalaman yang memadai untuk bisa diterapkan dan digunakan dalam kegiatan belajar, bekerja serta di berbagai aspek kehidupan lainnya. Keberhasilan proses pembelajaran mata pelajaran TIK, dapat dilihat dari hasil belajar yang dicapai oleh para siswa. Hasil belajar yang tinggi selalu menjadi tujuan dari proses pembelajaran. Pencapaian prestasi belajar siswa sangat ditentukan oleh berbagai faktor, salah satu faktor tersebut yaitu media pembelajaran yang digunakan (Sudrajat,2008).

Media pembelajaran biasanya dapat dibuat oleh guru/pendidik/pengajar. "Fungsi media pembelajaran adalah sebagai pembawa informasi dari sumber (guru) menuju penerima (siswa)" (Santyasa, 2007). Media merupakan alat untuk mendeskripsikan suatu informasi agar informasi yang disampaikan dapat lebih jelas untuk dimengerti dan dipahami. Jika dalam proses belajar mengajar guru atau tenaga pengajar mampu menyajikan materi dengan desain menarik dan berkualitas maka siswa akan lebih tertarik untuk mempelajari materi tersebut. Media berfungsi untuk mengarahkan siswa untuk memperoleh berbagai pengalaman belajar. Pengalaman belajar (learning experince) tergantung pada interaksi siswa dengan media. Media yang tepat sesuai dengan tujuan akan mampu meningkatkan pengalaman belajar yang mampu mempertinggi hasil belajar (Rohani, 1997).

Berdasarkan uraian di atas, untuk membantu siswa dalam memahami materi pelajaran TIK akan dibuat sebuah media pembelajaran. Penelitian ini dapat memberikan manfaat diantaranya, (1) Bagi Siswa,dengan digunakannya media pembelajaran berbasis website dalam mata pelajaran TIK, diharapkan siswa mampu belajar dengan cara yang lebih bervariasi, menarik, dan memberikan waktu tambahan bagi siswa untuk belajar karena dapat digunakan dan dipelajari di luar jam pelajaran sekolah. Materi pelajaran yang diberikan akan lebih bermakna bagi siswa sehingga diharapkan mampu meningkatkan kualitas proses pembelajaran itu sendiri.(2) Bagi Guru, memudahkan guru dalam penyampaian materi pembelajaran serta dapat mewujudkan proses pembelajaran yang lebih berkualitas, menarik dan dapat merangsang siswa untuk belajar mandiri dan interaktif.

\section{Metode Penelitian}

Desain pembelajaran dapat dimaknai dari berbagai sudut pandang, misalnya sebagai disiplin, sebagai ilmu, sebagai sistem, dan sebagai proses. Sebagai disiplin, desain pembelajaran membahas berbagai penenlitian dan teori tentang strategi serta proses pengembangan pembelajaran dan pelaksanaannya. Sebagai ilmu, desain pembelajaran merupakan ilmu untuk menciptakan spesifikasi pengembangan, pelaksanaan, penilaian serta pengelolaan situasi yang memberikan fasilitas pelayanan pembelajaran dalam skala makro dan mikro untuk berbagai mata pelajaran pada berbagai tingkatan kompleksitas. Sebagai sistem, desain pembelajaran merupakan pengembangan sistem pembelajaran dan sistem pelaksanaanya termasuk sarana serta prosedur untuk meningkatkan mutu belajar (Supriatna dan Mulyadi, 2009).

Penelitian pengembangan adalah suatu proses untuk mengembangkan dan memvalidasi produk berupa materi, media, alat dan atau strategi pembelajaran yang akan digunakan dalam pendidikan. Pada 
penelitian ini produk yang dikembangkan adalah Media Pembelajaran pada Mata Pelajaran TIK. Dalam pengembangan ini, peneliti menggunakan fasilitas dari web, dimana web adalah fasilitas hypertext yang mampu menampilkan data berupa teks, gambar, suara, animasi, dan multimedia lainnya, di mana di antara data-data tersebut saling terkait dan berhubungan satu dengan yang lainnya. Untuk memudahkan dalam membaca data tersebut diperlukan sebuah web browser seperti Internet Explorer, Netscape, Opera, maupun Mozilla Firefox (Slamet, t.t.).

Teknologi web yang diadopsi untuk basis pengembangan media dalam penelitian ini, maka kelebihan media pembelajaran berbasis web merujuk pada keunggulan web itu sendiri. Keunggulan dan kelebihannya adalah, 1) Web sebagai ikon paling menonjol di internet, adalah aplikasi paling dinamis dan paling banyak dimanfaatkan oleh manusia, 2) Daya tarik visual web sangat dinamis, 3) awalnya web hanya mampu menampilkan teks, maka saat ini juga mampu menampilkan animasi, simulasi, bahkan video, 4) Perbedaan menonjol antara web dengan aplikasi dekstop adalah keberadaan hyperlink. Hyperlink inilah yang menjadi ciri dari kelebihan web, 5) Fleksibelitas dengan teknologi web sangat dimungkinkan. 6) navigasi pada web sebagai guiding tool untuk arah pembelajaran. Navigasi dapat diartikan sebagai petunjuk bagi pengguna saat ia menjelajahi materi dari suatu halaman web.

Media pembelajaran sebagai alat bantu dalam proses pembelajaran khususnya pada mata pelajaran TIK pokok bahasan perangkat lunak pengolah angka karena jumlah komputer yang ada di laboratorium komputer yang tidak sebanding dengan jumlah siswa setiap kelas sehingga siswa dapat berinteraksi dengan temannya dan dapat mengetahui kekurangan dan kelebihan dari diskusi yang berlangsung di kelas melalui media pembelajaran yang disediakan. Sehingga pemikiran siswa menjadi lebih luas dan pada dasarnya siswa memiliki cara yang berbeda-beda dalam menyerap materi pelajaran yang diberikan oleh guru.

Penelitian ini termasuk penelitian pengembangan. Model pengembangan yang digunakan yaitu model pengembangan Dick and Carey. Langkah pada model Dick and Carey menunjukan hubungan yang sangat jelas, dan tidak terputus antara langkah yang satu dengan yang lainya. Dengan kata lain, sistem yang terdapat pada Dick and Carey sangat ringkas, namun isinya padat dan jelas dari satu urutan ke urutan berikutnya (Supriatna, 2003). Pada perancangan suatu penelitian pengembangan pendidikan, penulis beranggapan model Dick and Carey adalah model pengembangan yang tepat. Selain itu penulis juga menggabungkan model pengembangan Dick and Carey ini dengan model pengembangan waterfall. Penulis menggunakan waterfall dikarenakan penulis beranggapan bahwa waterfall adalah model yang tepat untuk mengembangkan suatu software yang berbasis pendidikan dengan menggabungkannya bersama model Dick and Carey.

Uji coba produk dalam penelitian pengembangan ini terdiri atas : 1) Rancangan uji coba, 2) subyek coba, 3) jenis data, 4) instrumen pengumpulan data, dan 5) teknik analisis data. Dalam penelitian pengembangan ini digunakan dua teknik analisis data, yaitu teknik analisis deskriptif kualitatif dan analisis deskriptif kuantitatif. Teknik analisis deskriptif ini digunakan untuk merevisi media pembelajaran yang sedang dikembangkan. Data diperoleh dari hasil review ahli isi bidang studi atau mata pelajaran, ahli desain pembelajaran, ahli media pembelajaran, guru dan hasil uji coba siswa. Teknik analisis data ini dilakukan dengan mengelompokkan 
informasi-informasi dari data kualitatif yang berupa masukan, tanggapan, kritik, dan saran perbaikan yang terdapat pada angket dan hasil wawancara. Analisis desktiptif kuantitatif adalah suatu cara pengolahan data yang dilakukan dengan jalan menyusun secara sistematis dalam bentuk angka-angka dan atau presentasi, mengenai suatu objek yang diteliti, sehingga diperoleh kesimpulan umum. Dalam penelitian ini, analisis deskriptif kuantitatif digunakan untuk mengolah data yang diperoleh melalui kuesioner dalam bentuk skor.

\section{Hasil Penelitian dan Pembahasan}

Berdasarkan hasil perhitungan uji ahli mata pelajaran diperoleh tingkat pencapaian $91,4 \%$ sehingga berada pada kualifikasi sangat baik. Berdasarkan hasil perhitungan uji ahli media pelajaran diperoleh tingkat pencapaian 92,00\% sehingga berada pada kualifikasi sangat baik. Berdasarkan hasil perhitungan uji ahli desain pelajaran diperoleh tingkat pencapaian $90,78 \%$ sehingga berada pada kualifikasi sangat baik.

Sebagai produk pengembangan yang telah direvisi berdasarkan penilaian dari ahli isi mata pelajaran, ahli media, dan ahli desain pembelajaran, selanjutnya dilakukan uji coba perorangan terhadap media yang dikembangkan. Sebagai subyek dari uji coba perorangan ini adalah siswa SMP Negeri 4 Denpasar sejumlah tiga orang. Rerata persentase sebesar $90,67 \%$ berada pada kualifikasi sangat baik.

Setelah selesai melalui uji coba perorangan, media yang dikembangkan dalam penelitian ini dilanjutkan dalam tahap uji coba kelompok kecil. Dalam uji coba kelompok kecil, subyek coba dalam penelitian ini adalah siswa kelas VIII SMP Negeri 4 Denpasar sebanyak 12 orang. Rerata persentase $92,67 \%$ berada pada kualifikasi Sangat Baik.
Sebagai produk pengembangan yang telah direvisi berdasarkan masukan dari ahli isi mata pelajaran, ahli media, ahli desain media pembelajaran, uji coba perorangan, dan uji coba kelompok kecil, selanjutnya dilaksanakan uji coba lapangan. Sebagai subyek coba dalam uji coba lapangan yaitu kepada satu kelas yakni kelas VIII.2 dengan jumlah siswa sebanyak 35 orang siswa SMP 4 Denpasar. Rerata persentase sebesar 93,14\% berada pada kualifikasi Sangat Baik.

\section{Gambar dan Tabel}

Tabel 1. Konversi tingkat pencapaian

\begin{tabular}{|c|c|}
\hline $\begin{array}{c}\text { Tingkat } \\
\text { Pencapaian(\%) }\end{array}$ & Kualifikasi \\
\hline $90-100$ & Sangat baik \\
\hline $80-89$ & Baik \\
\hline $65-79$ & Cukup \\
\hline $55-64$ & Kurang \\
\hline $0-54$ & Sangat kurang \\
\hline
\end{tabular}

\section{Kesimpulan dan Saran}

Berdasarkan hasil pembahasan dan analisis yang telah dilakukan, maka dapat ditarik kesimpulan bahwa pengembangan media pembelajaran pada mata pelajaran TIK kelas VIII semester II di SMP Negeri 4 Denpasar dinyatakan layak guna dengan hasil penelitian atau ujicoba sebagai berikut. (1) Ahli isi/subtansi materi yaitu guru mata pelajaran bersangkutan dengan tingkat pencapaian 91,4\% dalam kategori sangat baik. (2) Ahli media pembelajaran dengan tingkat pencapaian $92,00 \%$ dalam kategori sangat baik. (3) Ahli desain pembelajaran dengan tingkat pencapaian $90,76 \%$ dalam kategori baik. (4) Uji coba perorangan dengan tingkat pencapaian yang diperoleh adalah 90,67\%dalam kategori baik.(5) Uji coba kelompok kecil dengan tingkat pencapaian yang diperoleh adalah 92,67\% dalam kategori baik.(6) Uji coba lapangan dengan tingkat pencapaian yang diperoleh adalah 93,14\% dalam kategori sangat baik. 
Saran-saran yang disampaikan berkenaan dengan pengembangan media pembelajaran pada mata pelajaran TIK kelas VIII semester II di SMP Negeri 4 Denpasar yaitu penelitian pengembangan media ini dapat dilanjutkan kedalam sebuah penelitian eksperiment sehingga didapatkan hasil yang lebih valid terhadap hasil belajar siswa.

\section{Daftar Pustaka}

Agung, A.A. gede. 2010. Evaluasi Pendidikan. Singaraja : Undiksha.

Rohani, Ahmad. 1997. Media Instruksional Edukatif. Jakarta : PT Rineka Cipta.

Santyasa, I W. 2003. Landasan Konseptual Media Pembelajaran. Singaraja : Undiksha.

Slamet, R. (t.t.). "Membangun Website dengan Adobe Photoshop dan MacromediaDreamweaver".Tersedia padahttp://duniadownload.com/eboo k-gratis-design/ebook-webprofessional-denganphotoshopdreamweaver.html. (Diaksestanggal 10 Desember).

Slavin, Robert E. 2008. Cooperative Learning Teor, Riset, dan Praktik. Bandung : Nusa Media.

Sudrajat,Akhmat. 2008. $\quad \underline{\text { Media }}$ Pembelajaran. http://Blog.WordPress.com (diakses tanggal 10 Desember 2011).

Supriatna, Dadang. 2003. Konsep Dasar Desain Pembelajaran. (Tidak diterbitkan). Makalah disampaikan pada Diklat E-Training PPPPTK TK dan PLB. Pusat Pengembangan Dan Pemberdayaan Pendidik Dan Tenaga Kependidikan Taman Kanak Kanak Dan Pendidikan Luar Biasa.
Tegeh, I Made dan I Made Kirna. 2010. Metode Penelitian Pengembangan Pendidikan. Singaraja : Universitas Pendidikan Ganesha. 